\title{
Ardeth
}

A magazine on the power of the project

$7 \mid 2020$

Europe

\section{Whatever Happened to Supranational Architecture?}

Sebastiano Fabbrini

\section{(2) OpenEdition \\ 1 Journals}

Electronic version

URL: https://journals.openedition.org/ardeth/1833

ISSN: 2611-934X

\section{Publisher}

Rosenberg \& Sellier

\section{Printed version}

Date of publication: 1 December 2020

Number of pages: 85-105

ISSN: 2532-6457

\section{Electronic reference}

Sebastiano Fabbrini, "Whatever Happened to Supranational Architecture?", Ardeth [Online], 7 | 2020

Online since 01 June 2021, connection on 25 June 2021. URL: http://journals.openedition.org/ardeth/ 1833 


\section{Whatever Happened to Supranational Architecture?}

Sebastiano Fabbrini

\section{Abstract}

The process of European integration is often described in architectural terms, starting with the metaphor of a common European house. This paper weights the ubiquitous rhetoric of a supranational architecture against the largely unexplored reality of the actual architecture that has been built to house the European institutions. The focus is on the place and time that have experienced the largest production of architectural hardware: Brussels between 1958 and 1992. Most of the Quartier Européen was built in this window, while the institutions did not have a permanent status and therefore struggled to gain agency over the transformations of the city. On the one hand, the goal is to question how operating for a new and unique structure of power influenced the production of architecture. On the other hand, this is an opportunity to start discussing how architecture contributed to shaping the European Union.
Affiliatio

Università luav di Venezia, Dipartimento di Culture del Progetto.

Contacts: sfabbrini [at] iuav [dot] it

Received:

17 April 2020

Accepted:

7 December 2020

DOI:

10.17454/ARDETH07.06

ARDETH \#07 


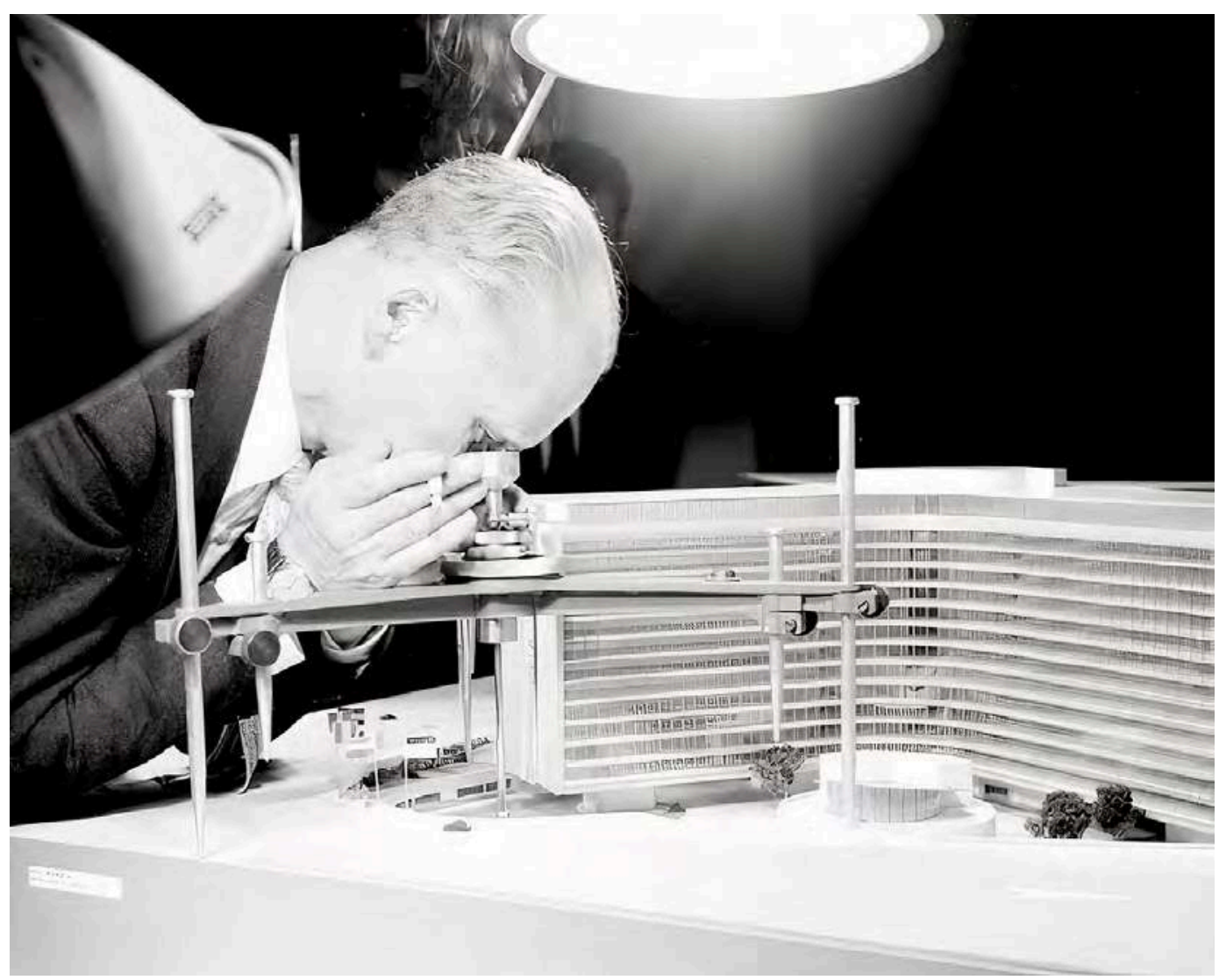

Fig. 1 - A fonctionnaire inspects a maquette of the Berlaymont, headquarters of the European Commission, late-1960s. Source: Ministère des Travaux Publics de Belgique.

Source: The author.

\section{Europe / European Union}

To address the theme of this special issue of Ardeth, titled Europe: Architecture, Infrastructure and Territo$r y$, the first step has to be a clarification, pertaining to both language and content. The discourse on this topic has continuously been accompanied by an ambiguity, which has generated a multitude of misunderstandings, between two different terms: Europe and the European Union (along with its previous incarnations). This distinction refers to another set of terms that have often been confused: Europeanization and European integration.

In his essay, What is so European about the European Union? Peter Burgess has gone to the core of this rift, underlining the tension between "an understanding of Europe as purveyor of a certain kind of cultural identity and the more of less bureaucratic project of European construction undertaken in its name” (Burgess, 2002). Part of the confusion has to do with 
the fact that these terms are difficult to define. One aspect that certainly sets them apart is their historical breadth. European integration is a recent phenomenon, with a specific start date: it formally began with the signing of the Paris Treaty in 1951, which established the European Coal and Steel Community. In the joint statement issued on that occasion by the foreign ministers of the six founding countries - Belgium, France, Italy, Luxembourg, Netherlands and West Germany - the new community was described as "the first supranational institution" in Europe (Haas, 1958). That being said, anyone willing to explore the vast literature on European integration will have a hard time finding a clear definition of this phenomenon. The one defining feature on which there is broad consensus is that European integration is a process. Historian Desmond Dinan has described it as a "voluntary sharing of national sovereignty in a supranational entity subject to the rule of law" (Dinan, 2006). So, it comes down to a group of states gradually agreeing to a common set of rules and institutions. Not to be confused with the age-old, elusive idea - started as a myth - of Europe.

Even though European integration has taken centre stage in a multitude of disciplines, from political science to law and economics, this is not the case when it comes to architecture and urban studies. In the introduction to his seminal book on the identity of European architecture, for example, Vittorio Gregotti prefaces his analysis by saying that it "prescinds completely from the dynamics of the European Union"1 (Gregotti, 1999). The architectural discourse has often been considered too Eurocentric and too politicized: yet we have mostly ignored the political dynamic that, more than any other, has been transforming the European archipelago over the past seventy years.

\section{Brussels's hardware}

Brussels is the most appropriate place to start exploring how architecture contributed to shaping European integration, not only because it has been the epicentre of the architectural projects for the European Union, but also because, due its particular history and internal power dynamics, it can be read as a microcosm of integration. In the early 2000s, the European Commission organized a conference titled Brussels, Capital of Europe to
1 - Translated by the author.

The discourse on this topic has continuously been accompanied by an ambiguity between two different terms: Europe and the European Union. This distinction refers to another set of terms that have often been confused: Europeanization and European integration. 


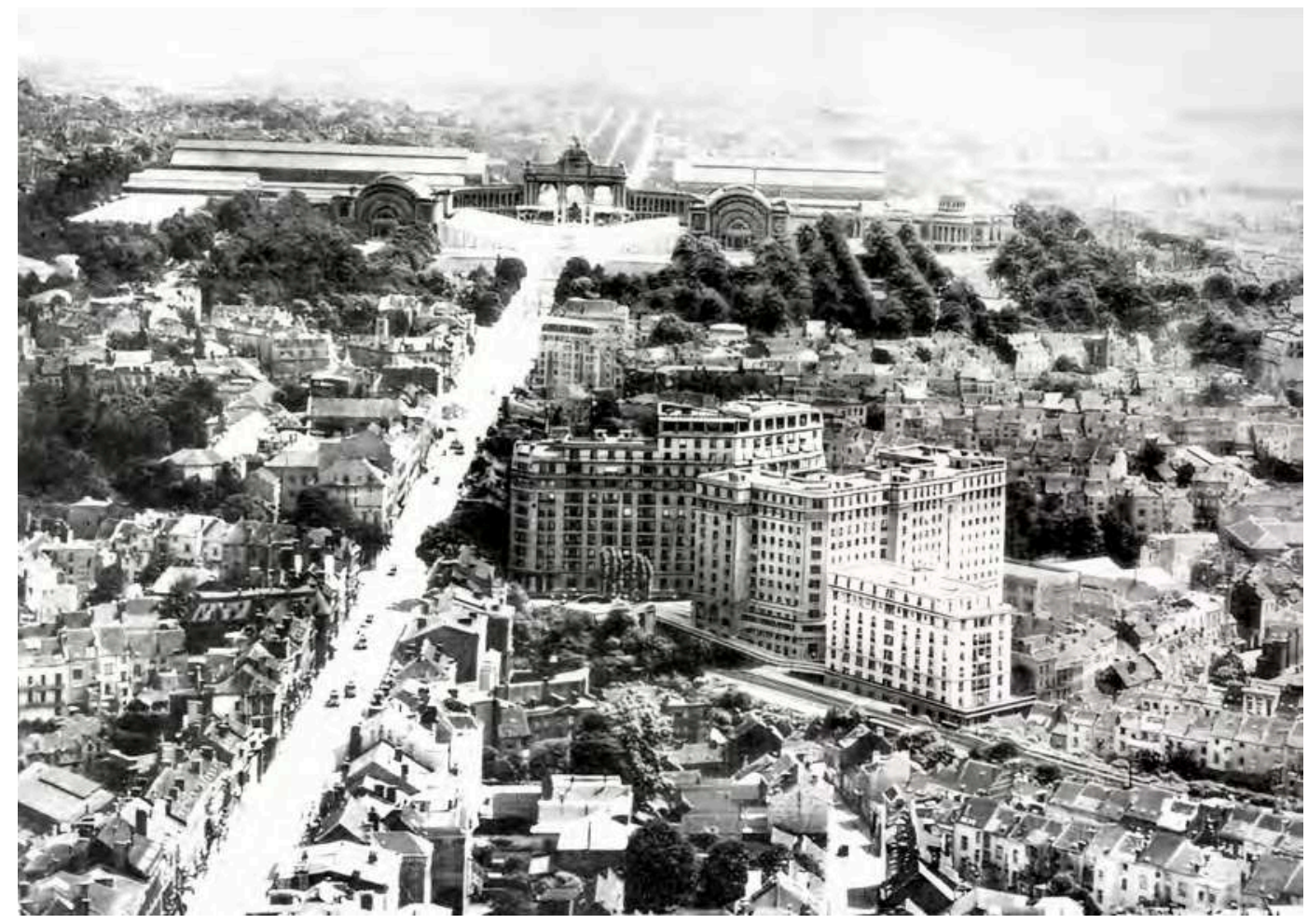

Fig. 2-3 - Brussels: aerial views of the Quartier Leopold in 1939 and 1999. Source: Centre Virtuel de la Connaissance sur l'Europe. "discuss the needs and functions of a European capital and how Brussels could best express them" (European Commission, 2001). The core of the event was a debate between Umberto Eco and Rem Koolhaas on how to approach the question of a supranational capital. Eco's argument revolved around the idea of a soft capital: "A European capital should deal with soft, not hard, business. So, allow me to smile when I hear that maybe we need to make a monument in order to give Brussels its character as the capital of Europe: an Empire State building, a Coliseum, or something like that - that is hard stuff".

The Dutch architect, on the other hand, was asked by the Commission to present the other side of the argument. For the conference, his team elaborated a presentation titled Communicating Europe, exploring ways to represent the European Union effectively. This study constituted the basis for the development of the exhibition The Image of Europe, which took place in Brussels three years later. The debate revolved around issues of representation - the question 


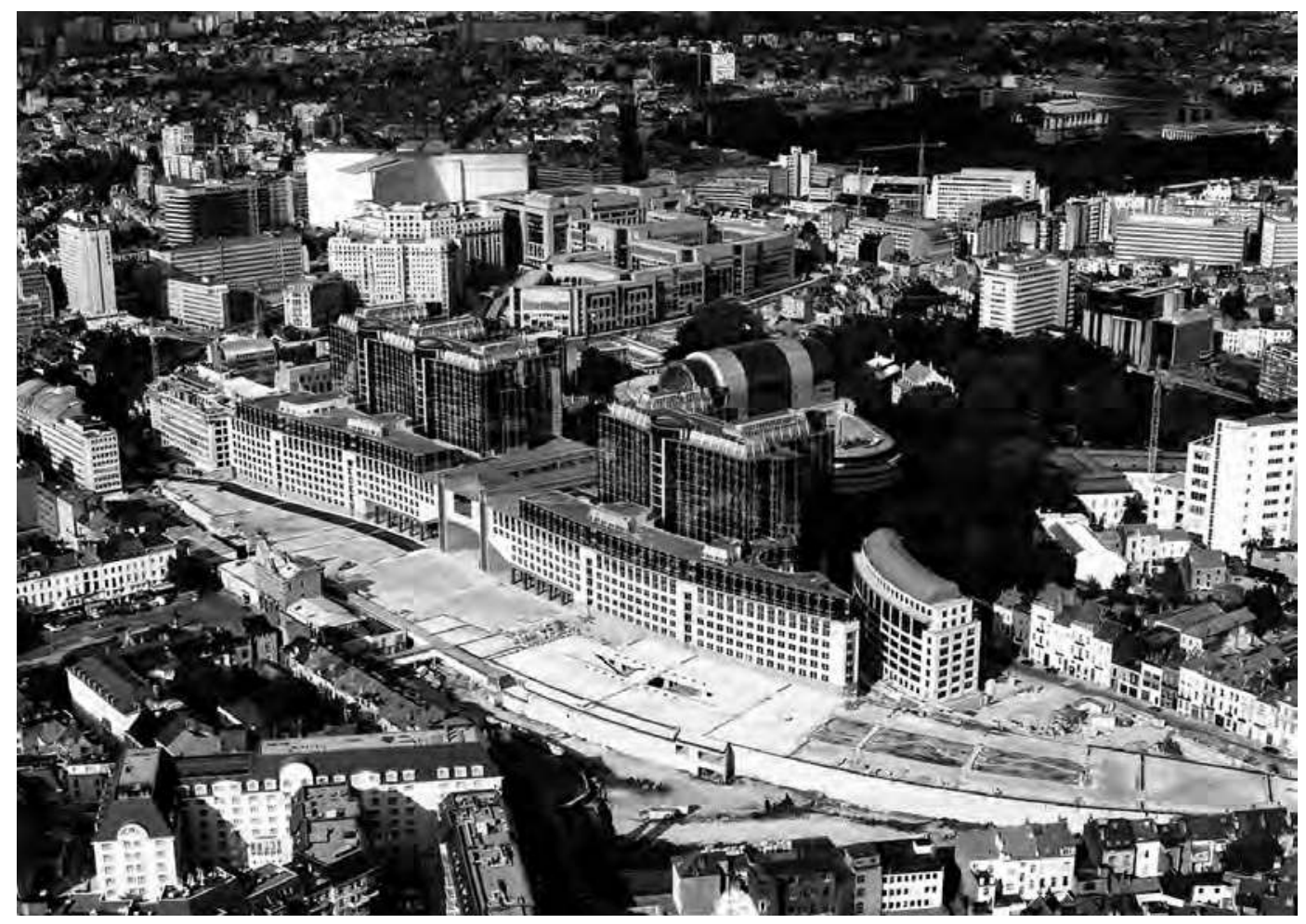

of Europe's image - conforming to a tendency to address the European district in Brussels as an immaterial entity. In the same period as the conference, Jean Baudrillard described it as "an abstract place" (Baudrillard, 2002).

However, the transformation of Brussels centred on the production of a massive amount of architectural hardware. In the most comprehensive study of this subject, Carola Hein underlined that Brussels was the city with the most significant increase of office space in continental Europe during the second half of the $20^{\text {th }}$ Century (Hein, 2004). According to the Atelier de Recherche et d'Action Urbaines, by the 2000s, the three major institutions alone - European Commission, Parliament and Council - occupied almost two million square meters of office space in the Belgian capital, spread among more than seventy buildings, inhabited by roughly fifty thousand employees (Arau, 2010). The opposition "soft capital versus hard capital" framed by the Commission responds to the same logic that informs the aforementioned dichotomy between

The opposition "soft capital versus hard capital” framed by the Commission responds to the same logic that informs the aforementioned dichotomy between the idea of Europe and the reality of the European Union. 
When the new institutions of the Community were scheduled to begin operations, the representatives of the member states had not yet found an agreement on a common location and, therefore, decided to start by rotating the meetings in their national capitals. the idea of Europe and the reality of the European Union. Overriding any speculation on what a united Europe ought to be or could have been, Brussels is the physical materialization of what the European Union actually is and has been so far. President Trump famously called Brussels a "hellhole" (Buruma, 2016). Steering clear of any value judgements, we shall approach it as a topia, as opposed to the utopias (and the dystopias) that are often associated with the integration process.

The impotent architect

In addition to its magnitude and the fact that very little attention has been paid to it, the transformation of Brussels has two distinctive characteristics. First, the majority of the aforementioned hardware was built over a 34-year period during which the Belgian city was indeed a seat of the European institutions, but only with provisional status.

Immediately after the signing of the Rome Treaty in 1957, which transformed the European Coal and Steel Community into the more ambitious European Economic Community, Brussels emerged as the "executive capital" of the new system, joining Strasbourg and Luxembourg, which had already been identified as the centres of the legislative and judicial powers. The first group of European officials, roughly three hundred people, moved to Brussels at the beginning of 1958. Notably, this was not the result of a clear plan: on January $1^{\text {st }}$, when the new institutions of the Community were scheduled to begin operations, the representatives of the member states had not yet found an agreement on a common location and, therefore, decided to start by rotating the meetings in their national capitals.

The rotation was based on alphabetical order, so Belgium was first. After the Commission settled in Brussels, however, it would have been very inconvenient to move, and everyone agreed to stay put. In other words, we would not be talking about Brussels if there was another member state that started with the letter "A” (Van Parijs, 2014).

That being said, Brussels's provisional status was due to more than this initial contingency. In fact, until the signing of the Maastricht Treaty in 1992, the process of European integration advanced under the assumption 
that one day all the institutions would be grouped in a single site, a federal capital on the model of Washington DC. For almost forty years, this idea, first outlined by Jean Monnet in the early 1950s, impeded any settlement of the European institutions from being regarded as permanent.

The second defining characteristic of Brussels's expansion is that, until 1992, due to the provisional status of their presence, the European institutions were not allowed to finance and own their buildings. Therefore, they had very little agency over the development of the Quartier Européen. At the same time, the host country was barred from building any permanent installation specifically designed for the European institutions (Lenaerts, Vanvoorden, 2008).

A 1978 report of the European Court of Auditors explains the situation in unequivocal terms: "The budgetary authorities have so far refused to allow the Community institutions to become owners of the properties they inhabit. The argument put forward by the budgetary authorities is political in nature and concerns the lack of any final decision over the official seat of the institutions" (European Court of Auditors, 1978).

As a result, the European institutions had to rent office space in buildings owned and designed by others - an exchange that, by the way, continued to take place well beyond the 1992 turn, because at that point it had become difficult to restructure a system that had been solidifying for decades. As highlighted in the report of the Court of Auditors, this situation proved to be extremely costly for the institutions and beneficial for local real-estate companies: a diagram developed by the firm Healey \& Baker shows a fivefold increase in the cost of rent in the Quartier Européen between the mid-1960s and 1990 (Healey \& Baker, 1990).

On the one hand, this particular condition shines a light on the structural impotence or powerlessness of the European Community as it pertained to the production of architecture throughout more than half of its history. On the other hand, it raises the question of how the massive conglomeration of architecture for the European institutions was produced during that time. Who produced it? What logic did they follow?
It raises the question of how the massive conglomeration of architecture for the European institutions was produced during that time. Who produced it? What logic did they follow? 
Fig. 4 - Letter concerning the "plan de cloisonnement" of the Berlaymont, 1969.

Source: European Commission.

\section{The Belgian} government was initially very sceptical about making a significant investment for an institution that was in town on a provisional basis and might have left after a short period of time.
The Berlaymont

The project that kickstarted and focalized the transformation of the Leopold Quarter, the area immediately south-east of Brussels's inner ring road, into a European district was the Berlaymont, the headquarters of the European Commission - an architectural endeavour that spanned almost the entirety of the aforementioned 34-year period of provisionality and powerlessness.

The idea of creating a major office building on the site of the Berlaymont monastery was put forward shortly after the first group of functionaries moved to Brussels in 1958 (Sterken, 2009). Three entities participated in this endeavour: the Belgian government, represented by its Ministry of Public Works, which owned the site and organized the transfer of the monastery to another location; the Belgian Office of Overseas Social Security, a social security fund designed to deal with international matters (following the dissolution of Belgium's colonial empire), which was brought in by the government to finance the construction of the new Berlaymont; and finally the local real estate company François et Fils, a powerful and very well politically connected company, which promoted the project, pitched the idea to the Commission and oversaw the construction process.

Even though François et Fils had approached the Commission as soon as the first officials arrived, the Belgian government was initially very sceptical about making a significant investment for an institution that was in town on a provisional basis and might have left after a short period of time. As noted in a report of the Council of the Brussels Capital Region, the solution was to develop the project on two levels: "Mais par précaution, le programme prévoit que le bâtiment puisse éventuellement abriter un ministère belge, au cas où les institutions européennes ne s'y installeraient pas" (Conseil de la Region de Bruxelles-Capitale, 2003).

When the maquette of the initial project - designed by local architects Lucien de Vestel, Jean Gilson, André and Jean Polak - was shown to the public in 1959, the presentation stated that the building could house either a national ministry or a European institution “éventuellement prétend-il" (De Beule, 2017). Although it had informally expressed its interest in 
COMMISSION

DES

COMMUNAUTES EUROPEENNES

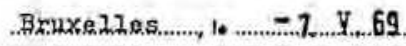

$I X / C / 810$

Note à l'attention de Monsieur FREDDI

Président de la Commission de contrôle

Ainsi que yous l'avez sans doute appris, le Conseil, dans le cadre du plan de regroupement des institutions européennes à Bruxelles, a décidé que les services de la Conmission seraient regroupés dans les complexes Berlaymont et Joyeuse Entrée - Cortenbeeg - Lo1, et devraient par conséquent abandonner tous les autres immeubles.

Ceci a donc pour conséquence que l'imneuble Archimède, où la Comission de contrôle est actuellement installée, doît être abandonné.

J'ai done l'honneur de vous faire connaftre qu'il vous est proposé de transférer vos services au 2ème étage du complexe Berlaymont, oủ 21 bureaux leur ont été réservés, ainsi que les salles d'archives H et I (voir plan cl-annexé).

Je vous saurais gré de bien vouloir me faire connastre quel plan de cloisonnement vous souhaitez voir réaliser.

Je vous signale à ce propos que le nonbre de bureaux accordé par le Conseil a conduit la Commiseion à satisfaire d'autre façon deux obligations traditionnelles :

- d'une part, les services ne pourront plus disposer de salles de réunions interneo, mais devront recourir à des salles mises en pool et gérées par la division IX/C/5, à laquelle elles devront être demandées ;

Adresse provisoire: 23-27, avenue de la Jayeuse Enträe, Bruxelles 4 - Taléphone 35.00.40 - 35.01,40 - Adresse télezrophique: .COMEUR Bnxelles: - Talex: COMEURBRU 21.877. 
One of the key issues had to do with the fact that multiple departments needed to operate with a high degree of "autonomie" and therefore could not be placed in an open space where others could physically interfere with their activities. occupying the Berlaymont from the get-go, the European Commission had no say over the design of the building. Suffice it to say that the initial project did not include appropriate facilities for translators, which are obviously essential to the functioning of a supranational institution. The architects, who had been single-handedly selected by the Belgian Ministry of Public Works (without a competition), were asked to design the interiors according to an open-plan layout, which aligned with the way work was organized and carried out in most Belgian government buildings. This layout, however, conflicted with the way the Commission operated. In 1968, when the building was completed, and the parties started to negotiate the lease, this issue came to the fore in a major way: the compromise came in the form of a sizeable discount on the rent.

Before the first fonctionnaire could start working in the Berlaymont, however, the entire interior had to be restructured. The correspondence between the Président de la Commission de Contrôle, the Directeur Général du Personnel et de l'Administration and the Chef de la Division Immeubles-Matériel-Service Intérieur during that time speaks to the tension that came with this process (European Commission, 1969). One of the key issues had to do with the fact that multiple departments, especially those that dealt with economic matters, needed to operate with a high degree of "autonomie" and therefore could not be placed in an open space where others could physically interfere with their activities. The solution was to implement a comprehensive "plan de cloisonnement," which turned the initial open layout into a maze of enclosed spaces, characterized by long, dark corridors, leaving many offices without windows.

\section{From poison to symbol}

After a long series of further modification, shortly before Brussels was recognized as a permanent seat of the European institutions, the perspective changed again in 1990, when vast quantities of asbestos were detected in the Berlaymont. Notably, a significant percentage of the 1400 tons of poisonous materials found in the building was embedded in the partitions that had been added over the years to create separate offices. The building could not be demolished because its foundations anchored the local road and metro net- 
work, so the parties decided to embark on a long and expensive renovation process. The Belgian government did not have the resources to pay for this project, so it teamed up with a number of private investors, mostly banks and financial institutions (Citibank, CGER, BACOB, among others), which set up a company called Berlaymont 2000 in order to fund and manage the renovation. In exchange for this investment, the company obtained from the government a long lease on the building, which was then sublet to the European Commission at a higher price.

When the asbestos crisis came up, several European officials proposed to take this opportunity to leave a building that had been designed for something else and never fit. However, the local authorities argued that the Berlaymont had become a "symbol" of the European presence in Brussels and therefore needed to be preserved (Shore, 2000).

By the same token, when the Commission decided to create a logo in the mid-2000s, the selected design centred on the silhouette of the Berlaymont (European Commission, 2017). In the end, a building that had been shaped by national agendas and private speculations, required constant modification and threatened the health of its inhabitants, ended up representing the "visual identity" of the supranational institution par excellence.

\section{Bruxellisation}

As evidenced by the case of the Berlaymont, the private sector played a crucial role in the transformation of Brussels. As noted by Alex Papadopoulos, Brussels is an atypical Western European capital because it was never subject to a comprehensive urban regulatory regime and most of its changes were based on private financing, following models of development that are often found in the United States (Padadopoulos, 1996).

Four years after the arrival of the European institutions, in 1962, Belgium made its first attempt at introducing a national regulation and passed the Loi Organique de l'Aménagement du Territoire et de l'Urbanisme. This regulatory regime characterized all the period during which Brussels acted as a provisional seat of the European institutions because it remained in force until 1991 when it was replaced by the Ordon-

\section{When the Commission decided to create a logo in the mid- 2000s, the selected design centred on the silhouette of the Berlaymont.}




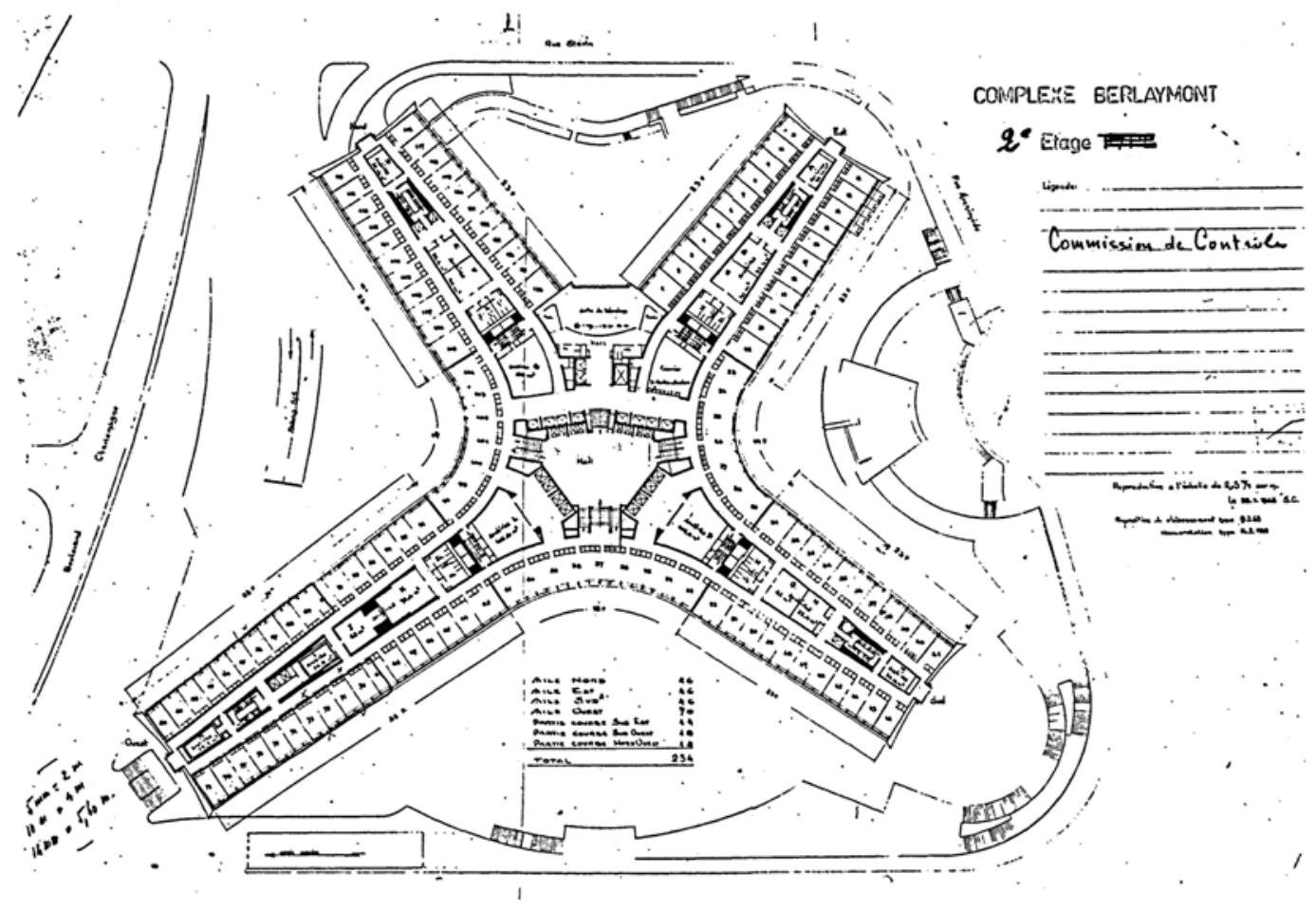

Fig. 5 - Plan of the Berlaymont after the reorganization of the interiors, 1969. Source: European Commission. 
nance Organique de la Planification et de l'Urbanisme. The "organic law" is well-known among planners because, rather than trying to guide the transformations of the city, it established a laissez-faire approach. The result was a process known as Bruxellisation - a term commonly used to indicate the demolition of large sections of the historic fabric of the city and the haphazard construction of high-rise office buildings (Kapplinger, 1993). Part of the problem was that Belgium, much like the European Union, is a federal system and, over the years, had to find ways to bring together a trilingual, tricultural population: any strict regulation imposed by the national government was unlikely to be easily accepted by these diverse communities, especially in the 1960s, a period of harsh confrontation between the Flemish and Walloon regions.

\section{Parliament in disguise}

Nowhere is the agency of private developers on the production of architecture for the European institutions clearer than in the case of the Spinelli building, the headquarters of the European Parliament in Brussels. If the vicissitudes of the Berlaymont speak mostly to the tensions associated with the early phases of the period under consideration, the Spinelli building relates to the other end of our timeline and shines a light on the turning point of 1992. In fact, the development of the hemicycle began in the mid-1980s and the complex was inaugurated in 1995.

As previously noted, the informal organizational structure of the EU indicated that the legislative branch was to be located in Strasbourg: the parliamentary assembly had been meeting in the French city since the birth of the European Coal and Steel Community. However, as more and more activities progressively coalesced in Brussels over the years, in the 1980s the European Parliament started to lobby in order to have a seat near the executive branch. The idea of moving to Brussels obviously clashed with the standpoint of the French government, which put its foot down to protect the Strasbourg headquarters. A 1987 Le Monde article titled Bataille pour un Hémicyle speaks to the level of tension that underlaid this discussion (Fralon, 1987). So how did the Parliament get around this obstacle?

A report of the Council of the Brussels Capital Region clearly states that, in 1988, "l'État belge a voulu

\section{The result was a process known as Bruxellisation - a term commonly used to indicate the demolition of large sections of the historic fabric of the city and the haphazard construction of high-rise office buildings.}




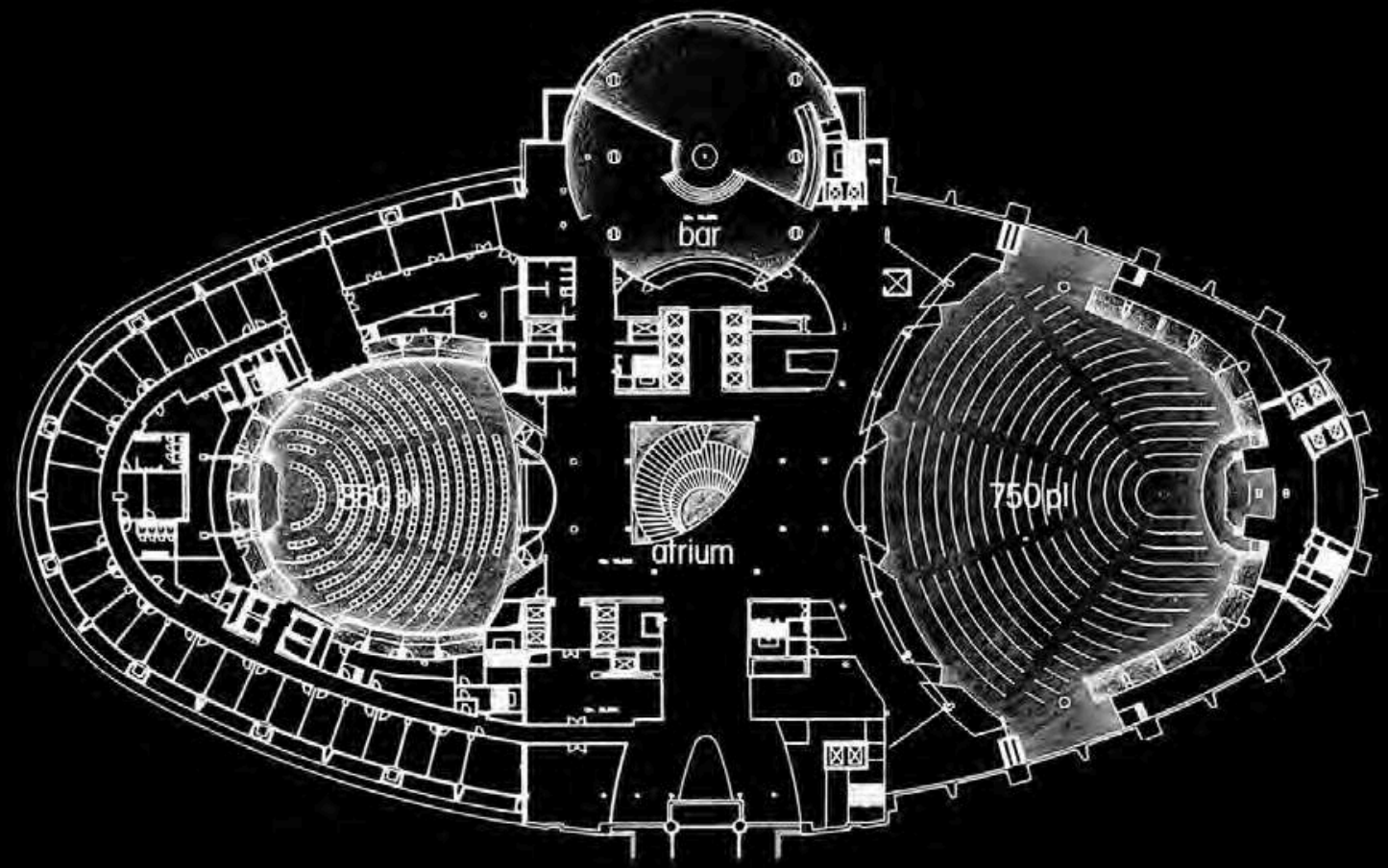

Fig. 6 - Plan of the

"Centre International de Conférences,"

1988. Source: Michel

Boucquillon.

Fig. 7 - Report of the developers of the "Centre International de Conférences," 2001

Source: Société Espace Léopold. 


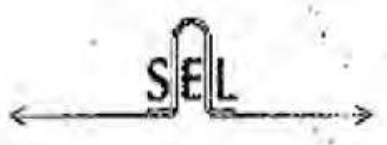

Dossier de presse

Décembre 2001

\section{L'aménagement du quartier Léopold : un projet qui remonte à 1987}

Si les grands projets urbanistiques sont toujours des entreprises de longue haleine, l'aménagement du quartier Léopold en est un bon exemple. Pour remonter aux sources de ce chantier, il faut en effet revenir à l'année 1987. A l'époque, la Région bruxelloise qui n'existait pas encore dans sa forme actuelle ambitionnait d'urbaniser le quartier. Elle avait alors chargé un bureau d'études de réaliser un projet global baptisé « Espace Bruxelles Europe ». Il portait sur le site de la gare Léopold, les terrains environnants et la création d'un Centre International de Conférences (CIC).

L'aménagement imaginé impliquait de construire une dalle de béton qui couvrirait les voies de chemins de fer. La dalle devenant une vaste esplanade flanquée d'immeubles. La philosophie de ce programme se fondait sur la mixité des fonctions. Il mariait en effet les ensembles de bureaux indispensables à la fonction de capitale européenne, les commerces, des salles d'exposition, des espaces publics et du logement. L'épure était séduisante restait à trouver l'amateur qui la concrétiserait.

C'est alors que le Groupement des Investisseurs entra en scène. Consortium formé de la $\mathrm{COB}$ et de la Société Générale de Belgique, le Groupement des Investisseurs signa (le 26 juin 1987) une convention avec la région bruxelloise. L'accord prévoyait que :

- le G.I. construirait simultanément la dalle et le CIC (futur D1/D2), en l'espace de 42 mois.

- Qu'ensuite, le G.I. construirait, selon le planning qu'il dẻterminerait, les autres bâtiments prévus dans le projet dans un délai ne pouvant dépasser 110 mois.

Les délais ne commençaient cependant à courir qu'à partir du moment où toute une série de conditions étaient remplies. Notamment la vérification de la faisabilité financière de l'opération, la délivrance du certificat d'urbanisme pour l'ensemble du projet, du permis de bâtir pour la dalle, pour les bâtiments à ériger sur cette nouvelle plate-forme, l'obtention du permis de bâtir pour le $\mathrm{ClC}$ et la cession de certains terrains. 


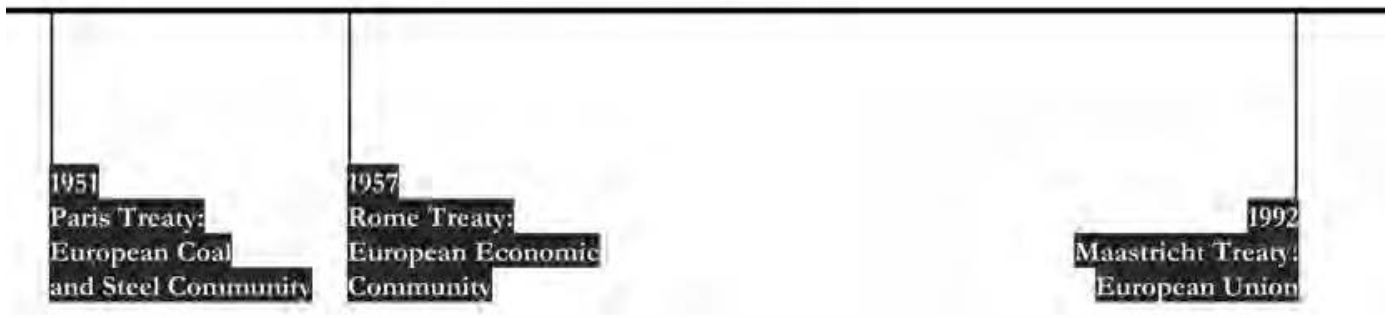

Brussels as a provisional capital

1958

Brussels becomes

a temporary capital

of the Community

Buildings

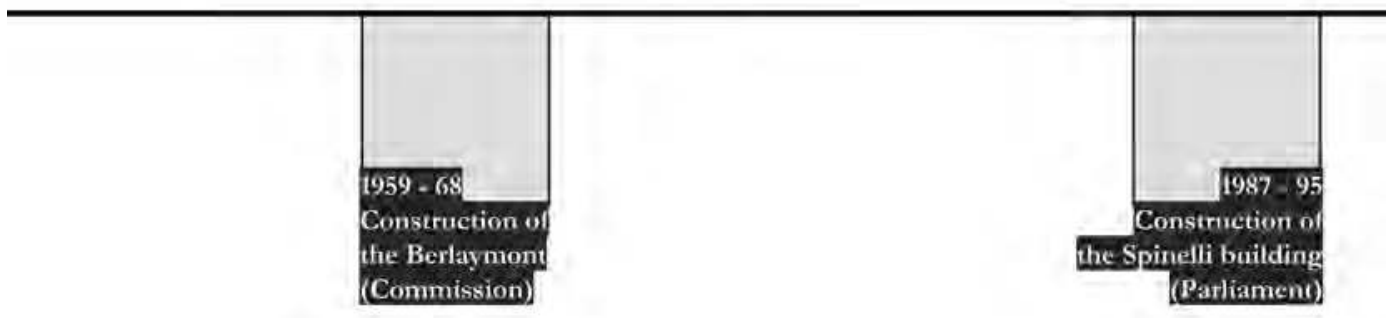

Regulatory framework

पत्र

Loi Organique de

PAménagement du Territoire

et de LUrbanisme
Brussels is recognized

as a permanent capital

of the European Union

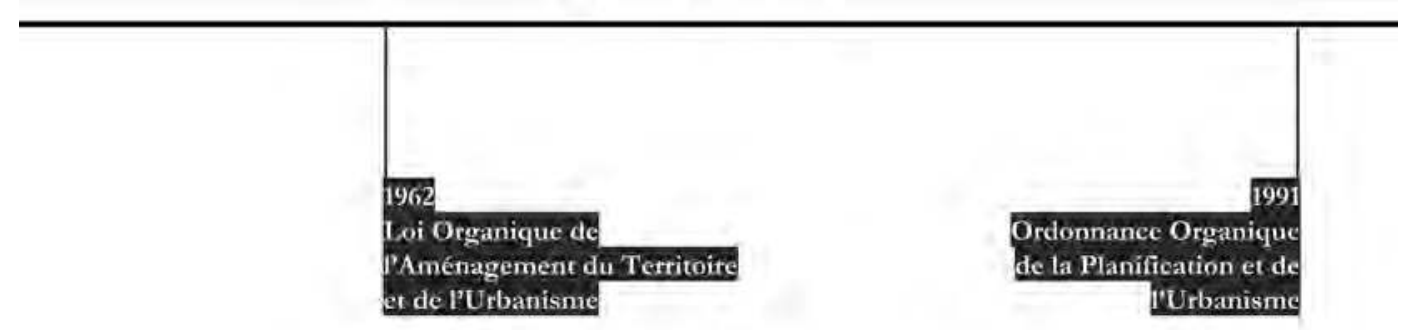


construire le siège du Parlement sans le dire officiellement; l'État belge trouve un groupement d'investisseurs, ou inversement d'ailleurs, et le groupement construit pour le compte officieux du Parlement et de l'État belge" (Conseil de la Region de Bruxelles-Capitale, 1991). This and many other documents point to the fact that Brussels's seat of the European Parliament was built in disguise (Lamant, 2018).

There was an informal agreement with the European institutions from the beginning but, as noted in another report of the Council, "la construction d'un hémicycle ont été formellement négociées avec les autorités européennes” (Conseil de la Region de Bruxelles-Capitale, 2003). The solution was to use a false name: instead of saying they were building a hemicycle for the European Parliament, the developers called it "Centre Internationale de Conférence", often shortened to the acronym "CIC".

The whole operation was promoted by a group of investors called Societé Espace Leopold, led by two Belgian banks: Société Générale de Belgique and BACOB, which was involved in the renovation of the Berlaymont too. These financial institutions owned the site of the Leopold brewery, less than a mile away from the Berlaymont. In June 1987, they signed an agreement with the government of the Brussels Capital Region and, in July 1987, obtained a building permit to demolish the existing structure of the brewery and build an "International Conference Centre" on the site (Papadopoulos, 1996).

The way in which the design was selected and developed was in line with the overall ethos of this project. The aforementioned consortium of banks and investors teamed up with a consortium of Belgian architects, which called themselves Association des Architectes du Centre Internationale de Conférence. The architectural firms that composed this association, however, were not interested in elaborating a design and, instead, organized an informal competition, aiming to find a proposal that was ready to be executed. The design ended up being produced by Michel Boucquillon, a 26-year-old, recently graduated, local architect, who was selected as the winner of this unusual contest.

From an institutional point of view, the informal agreement between the developers and the European
Fig. 8 - Timeline. Source: The author.

\section{The solution was to use a false name: instead of saying they were building a hemicycle for the European Parliament, the developers called it "Centre Internationale de Conférence”.}




\section{Given its}

complexity,

multiple theories

have been

developed over the

years to interpret

and explain

how the process

of European

integration works.

Architectural case

studies, however,

provide the unique

opportunity to

anchor these

reflections to

tangible objects.

\section{European}

integration poses

an existential

question: once

the possibility

of a blueprint is

negated a priori,

how does a

process produce

architecture? authorities was eventually legitimized by the 1992 decision regarding the status of the headquarters, which stated that Strasbourg would remain the primary seat of the Parliament and hold its monthly plenary sessions. However, all the additional sessions, as well as the meetings of the parliamentary committees, could take place in Brussels. Based on this arrangement, as soon as the "Centre Internationale de Conférence" was completed in 1995, the Parliament rented it and started to use the new hemicycle, ironically renaming it after Altiero Spinelli, whose idea of European integration had very little to do with this construction method.

Whatever Happened to Supranational Architecture? Given its complexity, multiple theories have been developed over the years to interpret and explain how the process of European integration works (Wiener and Diez, 2004). Architectural case studies such as the Berlaymont and the Spinelli building, however, provide the unique opportunity to anchor these reflections to tangible objects. For example, Lennaert Van Heumen and Mechthild Roos's theory of "informal integration" or Jack Hayward's theory of "integration by stealth" can be juxtaposed to the unofficial, behindthe-scenes, hidden practices that made these buildings possible (Van Heumen and Roos, 2019; Hayward, 1996). It is hard to find a clearer example of informal, stealthy architecture than the "Centre Internationale de Conférence."

Nonetheless, architecture has entered the discourse on European integration only on a metaphorical level. In one of the rare studies of this subject, Paul Chilton has highlighted the role of the metaphor of the "common European house" in the integration process (Chilton, 1993). However, there are many other examples: the publications on the "institutional architecture" of the European Union are too many to count. By the same token, Jean Monnet, Robert Schuman and the other founding fathers are constantly referred to as the architects of European integration.

Once we step away from this metaphorical dimension and start to look at the existing institutional architecture of the European Union - the one made of concrete, steel, glass (and occasionally asbestos) - we gain a different perspective. As in the cases of the buildings of the Commission and the Parliament, the 
two institutions that, more than any other, represent the transition from a system of divided nation-states to one of the integrated member states, the rhetoric of a supranational institutional architecture clash with the reality of a process of architectural production that responds primarily to local, regional, national and at most intergovernmental dynamics, with a strong influence of the private sector.

On the one hand, architecture serves as a testing ground. While most of the research on European integration deals with immaterial objects, architecture provides concrete case studies that can help us decipher how the European Union works. Being careful not to generalize and overreach, one may argue that exploring how these buildings are produced illuminates how things take form in this integrated system and how the European Union operates as a builder in other areas as well. On the other hand, the way the system is structured seems to challenge the very possibility of architecture. As underlined by Joschka Fischer in his influential speech Thoughts on the Finality of European Integration, European integration operates as "a gradual process with no blueprint” (Fischer, 2000). Since its inception, this has been the modus operandi: as early as 1950, the Schuman Declaration clearly stated that "Europe will not be made all at once, or according to a single, general plan; it will be built through concrete achievements” (Krijtenburg, 2012).

We are used to thinking that the presence of a blueprint, a plan or some kind of outline regarding how things need to unfold is the conditio sine qua non for the production of architecture. In our field, every "concrete achievement" is preceded by plans, elevations, sections. From this point of view, European integration poses an existential question: once the possibility of a blueprint is negated $a$ priori, how does a process produce architecture?

\section{References}

Arau: Atelier de Recherche et d'Action Urbaines (2010), Petite chronique du Ghetto Européen à son apogée, Brussels, Arau. Baudrillard, J. (2002), Europe, Globalization and the Destiny of Culture, "European Journal of Social Theory", vol. 5, n. 4, pp. 521-530.

\section{Exploring how these buildings are produced illuminates how things take form in this integrated system and how the European Union operates as a builder in other areas as well.}


Burgess, P. (2002), What's so European about the European Union? Legitimacy between Institution and Identity, "European Journal of Social Theory”, vol. 5, n. 4, pp. 465-479.

Buruma, I. (2016), In the Capital of Europe, "The New York Review of Books", April $7^{\text {th }}$.

Chilton, P. (1993), Metaphor in Political Discourse: The Case of the Common European House, "Discourse \& Society", vol. 4, n. 1, pp. 7-31.

Conseil de la Region de Bruxelles-Capitale (1991), Proposition de resolution relative au role de Bruxelles dans l'accueil des Institutions Européennes [Online]. Available at: https://www. moniteur.be [Accessed 15 November 2020].

Conseil de la Region de Bruxelles-Capitale (2003), Proposition de resolution concernant l'implantation des Institutions Européennes à Bruxelles [Online]. Available at: https://www. moniteur.be [Accessed: 15 November 2020].

De Beule, M. (ed.) (2017), Bruxelles, histoire de planifier: urbanisme aux 19e et 20e siècles, Brussels, Mardaga.

Dinan, D. (2006), Origins and Evolution of the European Union, Oxford, Oxford University Press.

European Commission (1969), Correspondence regarding the organization of office space in the Berlaymont [Online]. Available at: https://ec.europa.eu/historical_archives [Accessed: 15 November 2020].

European Commission (2001), Brussels, Capital of Europe [Online]. Available at: https://ec.europa.eu/historical_archives [Accessed: 15 November 2020].

European Commission (2017), Visual Identity Manual [Online]. Available at: https://ec.europa.eu/historical_archives [Accessed: 15 November 2020].

European Court of Auditors (1978), Note for the Attention of the Members of the Court of Auditors Concerning the Lease for a New Building [Online]. Available at: https://archives.eui.eu [Accessed: 15 November 2020].

Fischer, J. (2000), Thoughts on the Finality of European Integration [Online]. Available at: https://ec.europa.eu/historical_archives [Accessed: 15 November 2020].

Fralon, J. (1987), Bataille pour un hémicyle, "Le Monde”, July $2^{\text {nd }}$.

Gregotti, V. (1999), L'Identità dell'architettura europea e la sua crisi, Turin, Einaudi.

Haas, E. (1958), The Uniting of Europe, Stanford, Stanford University Press.

Hayward, J. (ed.) (1996), Elitism, Populism and European Politics, Oxford, Clarendon Press.

Healey \& Baker (1990), Growth of Rental Properties at the Quartier Européen, London, Healey \& Baker.

Hein, C. (2004), The Capital of Europe: Architecture and Urban Planning for the European Union, Wesport, Praeger. 
Kapplinger, C. (1993), Façadisme et Bruxellisation, "Bauwelt", vol. 84, n. 40, pp. 2166-2175.

Krijtenburg, M. (2012), Schuman's Europe, Leiden, Leiden University Press.

Lamant, L. (2018), Bruxelles Chantiers: Une Critique Architectural de l'Europe, Montreal, Lux.

Lenaerts, K., Vanvoorden, K. (2008), The Legal Status of Brussels as European Capital, in De Groof, R. (ed.), Brussels and Europe, Brussels, Academic and Scientific Publishers.

Papadopoulos, A. (1996), Urban Regimes and Strategies: Building Europe's Central Executive District in Brussels, Chicago, University of Chicago Press.

Shore, C. (2000), Building Europe: The Cultural Politics of European Integration, London, Routledge.

Sterken, S. (2009), Le Berlaymont et la Transformation du Quartier Leopold, "Journées du Patrimoine Région de Bruxelles-Capitale,” n. 15, pp. 102-117.

Van Heumen, L., Roos, M. (eds) (2019), The Informal Construction of Europe, London, Routledge.

Van Parijs, P. (2014), Why did Brussels Become the Capital of Europe? Because Belgium Starts with the Letter B, "The Brussels Times”, September.

Wiener, A., Diez, T. (eds) (2004), European Integration Theory, Oxford, Oxford University Press. 